\title{
Wskaźniki jakości demokracji w regionach Europy w latach 2016-2020. W kierunku erozji demokracji w państwach Europy Środkowej i Wschodniej?
}

\begin{abstract}
Streszczenie: Cechą wspólną w państwach Europy Środkowej i Wschodniej (EŚW) wydaje się być dość podobny poziom jakości demokracji. Celem artykułu jest przeanalizowanie, czy w państwach EŚW mamy obecne zjawisko odwrotu od demokracji oraz czy istnieją wyraźne różnice w poziomie demokracji między państwami EŚW a starymi państwami UE. Ocenie poddano wskaźniki jakości demokracji w grupach państw EŚW, Północnej, Południowej oraz Zachodniej. Analiza ujawniła, podobnie jak wcześniejsze badania litewskiego politologia Sauliusa Spurgi, iż nie ma wyraźnej różnicy między wskaźnikami grupy państw EŚW a grupą państw Europy Południowej (m.in. Hiszpanii, Portugalii, Grecji). Z kolei w przypadku państw skandynawskich i południowoeuropejskich pojawiają się istotne różnice w poziomie wskaźników demokracji. Dane wyraźnie wskazują wyższy poziom jakości demokracji w państwach skandynawskich. Potwierdzają to wyniki raportów jakości demokracji z lat 2006, 2008 oraz 2010. Na podstawie dokonanej analizy można stwierdzić, że różnice w jakości demokracji w grupie starych państw członkowskich UE są większe niż różnice pomiędzy państwami grupy EŚW a państwami Europy Południowej.
\end{abstract}

Słowa kluczowe: Europa Północna, Europa Południowa, EŚW, demokracja, indeksy, wskaźniki, jakość demokracji

\section{Wstęp}

Nónłczesne państwa Europy Środkowej i Wschodniej (dawniej państwa bloku wschodniego) są państwami o systemie demokratycznym i gospodarce wolnorynkowej. Są członkami Unii Europejskiej, NATO, ONZ, OECD i wielu innych organizacji międzynarodowych. Zgodnie z opinią Sauliusa Spurgi od dłuższego czasu panuje przekonanie, iż różnice w jakości demokracji, zarówno w sferze ekonomicznej, jak i społecznej, między państwami postkomunistycznymi a Zachodem będą się długo utrzymywać (Spurga, 2011, s. 148).

Powszechnie uważa się, że państwa EŚW stale doświadczają trudności związanych z procesem konsolidacji demokracji, a jakość demokracji w tych regionach pogarsza się. Jest to wynikiem rozmaitych kryzysów w UE (gospodarczy, finansowy, instytucjonalny, migracyjny, pandemia) oraz rządów populistycznych w wielu państwach, które obserwuje się od kilkunastu lat w Europie. Podkreślić należy, że panuje powszechne przekonanie, iż państwa postkomunistyczne pod względem standardów demokratycznych często odbiegają od państw, gdzie powszechnie funkcjonuje dojrzała demokracja. Zatem nasuwają się pytania o to, czy po ponad trzydziestu latach od upadku poprzedniego porządku politycznego w EŚW przeszłość komunistyczna jest nadal istotnym czynnikiem determinującym obecną sytuację demokratyczną w państwach EŚW? Czy można stwierdzić, że z punktu 
widzenia demokracji państwa te nadal znajdują się w fazie przemian? A może powinno się w tym przypadku mówić o odwrocie od demokratycznych wartości i zasad?

Formułując w ten sposób zadanie badawcze, dostrzec można różnice w jakości demokracji między nowymi członkami UE (państwami, które wstąpiły do Unii 1 maja 2004 r. i później) a tzw. starą piętnastką. Konstruując warsztat badawczy, pamiętać należy także, że grupa starych członków UE nie jest grupą jednolitą. Obejmuje ona bowiem państwa o różnych ustrojach politycznych, np. państwa Europy Północnej o głęboko ukorzenionych tradycjach demokratycznych, z drugiej zaś strony państwa Europy Południowej (m.in. Grecja, Hiszpania, Portugalia), w których w stosunkowo niedawnej przeszłości panowały rządy autorytarne, a problemy społeczne, gospodarcze i demokratyczne zostały uwydatnione przez światową pandemią COVID-19 oraz po przejęciu władz przez prawicowe populistyczne rządy.

Celem niniejszego artykułu jest zbadanie jakości demokracji w oparciu o wskaźniki jakościowe charakterystyczne dla poszczególnych państw. W zaprezentowanych badaniach porównano państwa Europy Północnej, Południowej i Środkowo-Wschodniej. W badaniach podjęto się zweryfikowania hipotezy, zakładającej, że jakość demokracji w EŚW jest na znacznie niższym poziomie niż w grupie dojrzałych demokracji zachodnich, wchodzących w skład UE. Wyniki tego zadania badawczego pozwolą odnieść się do stwierdzenia Sauliusa Spurgi, mówiącego, że państwa EŚW wciąż doświadczają postkomunizmu, a nawet odwrotu od demokracji (Spurga, 2011, s. 149).

W 1994 r. George Schopfin stwierdził, że wiele wskazuje na to, iż postkomunizm nie jest tylko stanem przejściowym, ale może być kluczowym elementem polityki regionalnej podczas próby przewidywania przyszłości państw z nim związanych (Schopfin, 1994, s. 128-130). W niniejszym tekście postanowiono porównać państwa grupy EŚW z Grecją, Hiszpanią i Portugalią, co uzasadnione jest podobnymi doświadczeniami historycznymi (do połowy lat 80 . autorytarne rządy, a następnie - w połowie lat 90 . XX wieku, intensywne procesy demokratyzacji) (Linz, Stepan, 1996, s. 45). Analizując funkcjonowanie demokracji w państwach Europy Środkowej i Wschodniej, można stwierdzić, że reżimy te nie spełniają wszystkich wymogów pełnych demokracji i działają nadal w wielu obszarach wadliwie. Świadczy o tym na przykład fakt, iż wiele organizacji pozarządowych, fundacji i agencji, które regularnie prowadzą bieżące badania w państwach przechodzących transformację ustrojową, nadal monitoruje państwa EŚW. Wymienić tu należy m.in.: Freedom House (badanie Nations in Transit), uSaID (badanie NGo Sustainability Index) oraz Fundację Bertelsmanna (badanie Bertelsmann Transformation Index). Niniejszy artykuł jest zatem próbą odpowiedzi na pytanie, czy systemy polityczne grupy państw EŚW i tzw. dojrzałych demokracji Europy faktycznie dzieli przepaść i czy jakość demokracji w grupie państw EŚW pogarsza się na tyle, że należy mówić o przedłużającej się transformacji postkomunistycznej, a dokładniej o odwrocie od demokracji tej grupy państw.

\section{Czym jest demokracja? Jej jakość i skale pomiaru}

Według Josepha Schumpetera demokracja jest instytucjonalnym rozwiązaniem dochodzenia do decyzji politycznych, w którym aktorzy polityczni uzyskują prawo do decydowania poprzez konkurencyjną walkę o głosy wyborców (Schumpeter, 2009, s. 336337). Robert Dahl krytycznie podszedł do koncepcji sprowadzenia demokracji wyłącznie 
do aspektu wyborów, z tego powodu przedstawił kryteria, które stały się punktem wyjścia dla wielu badaczy demokracji. Dahl wskazuje, że w demokracjach władze publiczne muszą zapewnić obywatelom: gwarancję podejmowania decyzji politycznych przez jednostki uczestniczące w wyborach; wybory powinny być przeprowadzone w sposób regularny, wolny i uczciwy; prawo wyborcze powinno być możliwie najbardziej inkluzyjne, a co za tym idzie wybory powinny przysługiwać wszystkim pełnoletnim osobom; bierne prawo wyborcze należne wszystkim pełnoletnim osobom, z uwzględnieniem instytucji, o którą toczy się rywalizacja (może obowiązywać inny cenzus wyborczy); wolność słowa; dostęp do alternatywnych źródeł informacji; wolność zrzeszeń, która umożliwia egzekwowanie zagwarantowanych praw oraz obejmuje możliwość formowania rozmaitych stowarzyszeń, organizacji, w tym również grup interesu i partii politycznych (Dahl, 2012, s. 316-317). Kryteria demokracji zaproponowane przez Dahla są często brane pod uwagę w dyskusjach na temat wskaźników jakości demokracji.

Larry Diamond i Leonardo Morlin zaproponowali osiem kryteriów, na podstawie których można ocenić jakość demokracji w danym państwie. Należą do nich: praworządność w państwie - wszyscy obywatele są równi wobec prawa; partycypacja - wszyscy pełnoletni obywatele muszą mieć prawo do udziału w życiu politycznym, w tym prawo do głosowania; rywalizacja polityczna - to nie tylko okresowe, wolne i uczciwe wybory, ale również odpowiedni poziom rywalizacji między siłami politycznymi; odpowiedzialność pionowa - obowiązek wybranych przywódców politycznych do odpowiedzialności za podejmowane decyzje przed wyborcami lub instytucjami konstytucyjnymi; odpowiedzialność pozioma - odpowiedzialność ponosi jedna gałąź rządu; wolność - obejmuje prawa polityczne, obywatelskie i społeczne; równość - w demokracji każdy obywatel i każda grupa obywateli ma te same prawa i taką samą ochronę prawną; wrażliwość - wolę obywateli należy przełożyć na decyzje polityczne (Diamond, Morlino, 2004, s. 20-31).

Uwzględniając powyższe, w niniejszej analizie wykorzystano następujące narzędzia pomiaru demokracji: Economist Intelligence Unit, udział obywateli w krajowych i europejskich wyborach parlamentarnych, zadowolenie obywateli ze sposobu funkcjonowania demokracji w ich państwie, a także raporty Freedom House. Prowadzona analiza nie zmierza w kierunku udzielenia uogólnionej odpowiedzi na pytanie, która grupa państw ma lepszą jakość demokracji. Zamierzeniem niniejszego przeglądu jest przeanalizowanie i porównywanie wskaźników jakości demokracji, a także stanu demokracji w grupach państw EŚW oraz wskazanie zasadniczych różnic pomiędzy tym regionem a grupami państw Europy Południowej, Północnej oraz Zachodniej. Cezura czasowa obejmuje lata 2016-2020 i została podyktowana możliwością dostrzeżenia różnic w wynikach dla poszczególnych państw, a także wskazania ewentualnych przyczyn zmian w analizowanych wskaźnikach.

\section{Indeks demokracji ${ }^{1}$}

W tabeli 1 i 2 zaprezentowano porównanie wybranych indeksów demokracji dla grupy państw Europy Północnej, Południowej i Środkowo-Wschodniej opracowane przez

${ }^{1}$ Indeks demokracji stanowi średnią ważoną w oparciu o uzyskane odpowiedzi na 60 pytań, z których każde posiada dwie lub trzy odpowiedzi do wyboru. Większość odpowiedzi to oceny zespołu ekspertów, a część z nich uzupełniono w oparciu o badania opinii publicznej, wykorzystując przy tym 


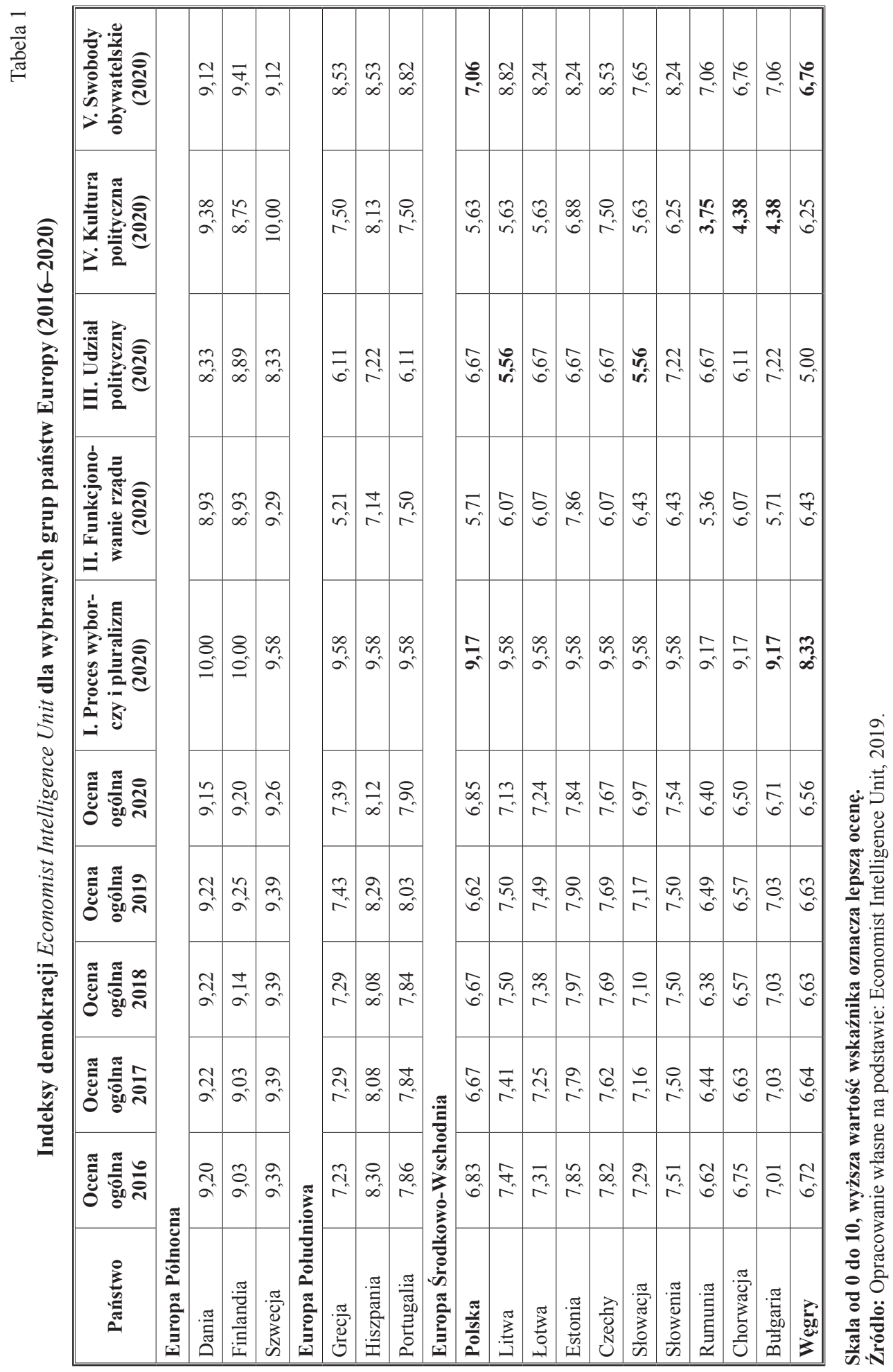


Economist Intelligence Unit ${ }^{2}$. Przedstawiono oceny ogólne w latach 2016-2020 i ogólne kategorie ocen. Średnia ocena dla wszystkich kategorii wskaźników państw Północnych w latach 2016-2020 jest wyższa od średnich wskaźników dla państw Europy Południowej. Stąd też ogólna ocena państw Europy Północnej pod względem wskaźnika demokracji jest wyższa. Wszystkie trzy państwa skandynawskie (Dania, Finlandia i Szwecja) w 2016, 2017, 2018, 2019 i 2020 r. spełniały kryteria pełnej demokracji. Hiszpania jako jedyne państwo Europy Południowej w latach 2016-2020 spełnia kryterium pełnej demokracji, ponieważ jej wynik w ogólnej ocenie jest powyżej 8 pkt.

Średnia ocena ogólna wspomnianych państw Europy Południowej w latach 20162020 jest wyższa niż w państwach EŚW. Obserwacja państw południowoeuropejskich z 2020 r., według pięciu kategorii demokracji, jest również lepsza niż państw EŚSW, za wyjątkiem pierwszej kategorii tj. procesu wyborczego i pluralizmu, w których to wartości wskaźników są niemal takie same (z wyjątkiem Rumunii, Bułgarii, Chorwacji, Polski i Węgier). Biorąc pod uwagę analizę indeksu z 2006, 2008 oraz 2010 r. zawartych w opracowaniu Sauliusa Spurgi należy zauważyć, iż utrzymała się stabilna tendencja państw Hiszpanii i Portugalii, które w latach 2016-2020 miały pełny status demokratyczny, podczas gdy Grecja utrzymuje status demokracji wadliwej. W 2010 r. Grecja straciła status pełnej demokracji, status ten do roku 2013 wśród grupy państw EŚW zachowało tylko jedno państwo tj. Republika Czeska - 8,06 (Economist Intelligence Unit, 2013).

Porównując lata 2016 oraz 2020 spadła średnia wartość indeksu demokracji dla państw Europy Północnej o 0,6 pkt i EŚW o 0,16 pkt, średnia wartość indeksu dla państw Europy Południowej utrzymała się na stałym poziomie tj. 7,8 pkt. Państwa Europy Południowej są znacznie bliżej państw EŚW niż państw Europy Północnej. W 2020 r. największa różnica między państwami Europy Południowej a EŚSW pojawia się w obszarze kultury politycznej, gdzie jedyna różnica w punktacji przewyższa 2 (najniższe wskaźniki odnotowano w Bułgarii, Rumunii i Chorwacji).

W tej kategorii ocenianych jest osiem wskaźników, w tym sondaże opinii publicznej m.in. nt. możliwości wprowadzania rządów silnej ręki czy np. potrzeby rządu technokratycznego. Różnica między państwami Europy Północnej i Południowej³ (zwłaszcza między państwami grupy Europy Północnej ${ }^{4}$ i Środkowo-Wschodniej ${ }^{5}$ ) przekracza pra-

badania World Values Survey, agencji Gallupa oraz Eurobarametru. Pytania pogrupowano na pięć kategorii: 1) proces wyborczy i pluralizm (12 pytań), 2) swobody obywatelskie (18 pytań), 3) funkcjonowanie władzy (14 pytań), 4) kultura polityczna obywateli (9 pytań), 5) partycypacja (7 pytań). Poszczególne odpowiedzi punktowano następująco: 1 pkt - demokratyczność, 0 pkt - niedemokratyczność, 0,5 pkt - odpowiedź pośrednia w sytuacji zmiennych podziału trójczłonowego. Punkty za uzyskane odpowiedzi w każdej z pięciu kategorii są dodawane, a w dalszej kolejności przeliczane proporcjonalnie na skalę od 0 do 10 , ponadto wartość ta jest modyfikowana w dół w przypadku, jeśli dany kraj nie spełnia kryteriów demokracji w kluczowych kwestiach. Całkowitą wartość indeksu ogólnego Economist Intelligence Unit stanowi średnia z wszystkich pięciu kategorii (Szewczyk, 2010, s. 127-128).

${ }^{2}$ Index jest średnią tych ocen. Przyjęto, że ocena powyżej 8,0 pkt oznacza pełną demokrację, od 6 do 7,9 to wadliwa demokracja, od 4 do 6 to system hybrydowy i do 4 pkt to system autorytarny.

${ }^{3}$ Hiszpania, Portugalia i Grecja.

${ }^{4}$ Szwecja, Finlandia i Dania.

${ }^{5}$ Polska, Litwa, Łotwa, Estonia, Czechy, Słowenia, Słowacja, Węgrzy, Rumunia, Bułgaria i Chorwacja. 
$\frac{\sqrt{\pi}}{\frac{\pi}{0}}$

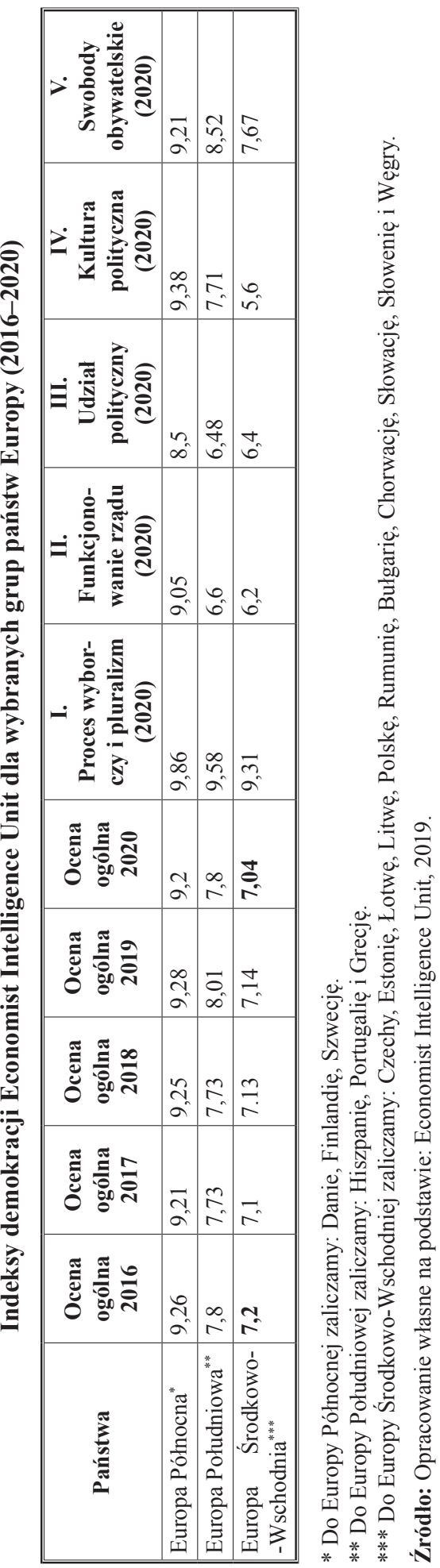


wie 3 pkt w kwestii funkcjonowanie rządu oraz 2 pkt w obszarze udziału politycznego. Economist Intelligence Unit, biorąc pod uwagę kryteria funkcjonowania rządu, ocenia w jakim stopniu parlamentarna kontrola różnych sfer życia jest skuteczna. Partycypacja polityczna obejmuje udział w wyborach, zainteresowanie obywateli polityką i ich zdolność do dokonywania wyboru siły politycznej ich reprezentującej.

Najmniejszą różnicę między wszystkimi trzema grupami państw Europy w $2020 \mathrm{r}$. odnotowano w kategorii procesu wyborczego i pluralizmu (niższe wartości wskaźnika miała Rumunia, Bułgaria, Chorwacja, Polska - 9,17 pkt i Węgry - 8,33 pkt). Poszczególne państwa Europy Północnej osiągają we wszystkich przypadkach lepsze wyniki niż państwa Europy Południowej i EŚSW. Wyjątek stanowi Szwecja w obszarze oceny procesu wyborczego i pluralizmu, który jest opiniowany jednakowo w dziesięciu państwach należących do trzech grup (wyróżniają się Dania i Finlandia, które mają najwyższy wynik). Nie ma jednak - podobnie jak sugerują wcześniejsze badania Sauliusa Spurgi z lat 2006, 2008, 2010 - wyraźnej granicy między poszczególnymi państwami Europy Południowej a państwami EŚW (Spurga, 2011, s. 166-167). Interesujący jest również fakt, że południowoeuropejskie państwo Grecja jest klasyfikowana jako „demokracja wadliwa".

\section{Udzial obywateli w krajowych i europejskich wyborach parlamentarnych}

Poziom udziału obywateli w elekcjach państwowych jest jednym z ważnych wskaźników jakości demokracji. Od poziomu zaangażowania obywateli - głównie w procesy wyborcze - zależy bowiem nie tylko poziom legitymizacji podejmowanych decyzji, ale także jakość rządów demokratycznych (por. Kapsa, Musiał-Karg, 2020). W tabeli 3 przedstawiono dane dotyczące frekwencji w ostatnich wyborach krajowych, a także frekwencję w ostatnich wyborach do Parlamentu Europejskiego. Statystycznie w państwach Europy Północnej w wyborach parlamentarnych uczestniczyło 80,17\% wyborców. Mieszkańcy wspomnianego obszaru byli średnio o 20,8 p.p. bardziej aktywni w porównaniu z wyborcami Europy Południowej. Spośród państw Europy Północnej najniższą frekwencję odnotowano w Finlandii, a z kolei w Europie Południowej w Hiszpanii. W przypadku wyborów do Europarlamentu odnotowano podobną tendencję, wskazującą, że wyborcy Europy Północnej wykazali się większą aktywnością niż wyborcy Europy Południowej.

W przypadku państw EŚW odnotowano średnio o 3,97 p.p. mniejszą aktywność w wyborach krajowych niż w państwach Europy Południowej. Kolejną kwestią jest fakt, że wyborcy ośmiu państw EŚW byli mniej bierni w wyborach krajowych niż Portugalia, gdzie frekwencja była najniższa wśród państw Europy Południowej. Warto zauważyć, iż najniższą frekwencję w grupie państw EŚW odnotowano w Rumunii $(31,84 \%)$.

Mieszkańcy państw Europy Południowej chętniej również uczestniczyli w wyborach do Parlamentu Europejskiego. Nie ma natomiast wyraźnej różnicy między wskaźnikami dla poszczególnych państw obu grup - Europy Południowej i Srodkowo-Wschodniej. $\mathrm{Na}$ Słowacji frekwencja w wyborach do Parlamentu Europejskiego wyniosła zaledwie 22,74\%, w Czechach 28,72\%, Słowenii 28,89\% oraz Chorwacji 29,85\%. Najwyższą frekwencję wyborczą pośród państw grupy EŚW odnotowano na Litwie (53,48\%). 
Udział ludności państw Europy Północnej, Południowej i Środkowo-Wschodniej w krajowych i w 2019 r. w europejskich wyborach do parlamentu

\begin{tabular}{|c|c|c|}
\hline Państwo & $\begin{array}{c}\text { Frekwencja w wyborach } \\
\text { krajowych }(\%)\end{array}$ & $\begin{array}{c}\text { Frekwencja w wyborach } \\
\text { europejskich w } 2019 \text { r. (\%) }\end{array}$ \\
\hline \multicolumn{3}{|l|}{ Państwa Europy Północnej } \\
\hline Dania & 84,60 & 66,08 \\
\hline Finlandia & 68,73 & 40,80 \\
\hline Szwecja & 87,18 & 55,27 \\
\hline \multicolumn{3}{|l|}{ Państwa Europy Południowej } \\
\hline Grecja & 57,78 & 58,69 \\
\hline Hiszpania & 71,76 & 60,73 \\
\hline Portugalia & 48,57 & 30,75 \\
\hline \multicolumn{3}{|l|}{ Państwa Europy Środkowo-Wschodniej } \\
\hline Polska & 61,74 & 45,68 \\
\hline Litwa & 47,80 & 53,48 \\
\hline Łotwa & 54,58 & 33,53 \\
\hline Estonia & 63,67 & 37,60 \\
\hline Czechy & 60,84 & 28,72 \\
\hline Słowacja & 65,81 & 22,74 \\
\hline Słowenia & 52,64 & 28,89 \\
\hline Rumunia & 31,84 & 51,20 \\
\hline Chorwacja & 46,90 & 29,85 \\
\hline Bułgaria & 53,85 & 32,64 \\
\hline Węgry & 69,67 & 43,36 \\
\hline \multicolumn{3}{|l|}{ Średnia } \\
\hline Państwa Europy Północnej & 80,17 & 54,05 \\
\hline Państwa Europy Południowej & 59,37 & 50,06 \\
\hline Państwa Europy Środkowo-Wschodniej & 55,40 & 32,70 \\
\hline Wszystkich państw & 64,98 & 45,60 \\
\hline
\end{tabular}

Uwagi: Ostatnie wybory krajowe do parlamentu odbyły się w Czechach, Bułgarii w 2017 r., na Łotwie, Szwecji, Węgrzech i w Słowenii w 2018 r., w Polsce, Danii, Finlandii, Grecji, Portugalii, Hiszpanii i Estonii w 2019 r., na Słowacji, Litwie, Rumunii, Chorwacji w 2020 r.

Źródło: Opracowanie własne na podstawie: Wyniki wyborów.., 2019.

Frekwencja w wyborach do Parlamentu Europejskiego była istotnie niższa we wszystkich trzech grupach państw w porównaniu z wyborami krajowymi i wyniosła średnio 19,38\%. Niższa w porównaniu do wyborów państwowych frekwencja w wyborach do PE jest wynikiem traktowania tych elekcji jako wyborów drugorzędnych (tzw. second order elections) - niemających tak dużego znaczenia dla polityki państwowej, jak wybory parlamentarne czy prezydenckie o charakterze krajowym (szerzej na ten temat: Kapsa, Musiał-Karg, 2020, s. 52-53).

\section{Zadowolenie obywateli ze sposobu funkcjonowania demokracji w ich państwie}

Oceniając zadowolenie obywateli ze sposobu funkcjonowania demokracji w ich państwie, można stwierdzić, że mieszkańcy państw Europy Północnej są dużo bardziej usatysfakcjonowani z tego, jak działa u nich demokracja niż obywatele państw Europy Połu- 
dniowej (patrz: tabela 4). Według danych z roku 2016 różnica stopnia zadowolenia między państwami wspomnianych regionów jest naprawdę wyraźna i wynosi 50,4\%. Z kolei w latach 2016, 2018 i 2019 odnotowano większe zadowolenie z panującej demokracji wśród obywateli państw EŚW w porównaniu z Europą Południową. Wraz z mijającym czasem na podstawie przeprowadzanych badań zaobserwowano wzrost stopnia zadowolenia w grupie mieszkańców państw EŚW. Różnica w zadowoleniu z demokracji we własnym państwie jest znacznie większa między państwami Europy Północnej a Południowej niż pomiędzy państwami Europy Południowej a EŚW. Jeżeli weźmiemy pod uwagę, opracowane przez litewskiego politologa Spurgisa, dane z lat 2005, 2006 oraz 2009, to zauważymy zmianę tendencji w trendach dotyczących zadowolenia obywateli z panującej demokracji w grupie państw Europy Południowej i EŚW (Spurga, 2011, s. 171).

Według danych Eurobarometr ${ }^{6}$, wartości wskaźników dla poszczególnych państw pokrywają się w różnych grupach państw. W 2016 r. wartość wskaźnika Hiszpanii przewyższała wartość wskaźnika Rumunii, Bułgarii, Litwy i Słowenii. W 2017 r. wskaźnik Portugalii przekroczył wartość jedenastu państw EŚW. W 2018 r. Hiszpania przekroczyła wartość indeksu Litwy, Rumunii, Bułgarii i Chorwacji, a różnice w porównaniu z pozostałymi dwoma państwami EŚW (Słowacji i Słowenii) nie przekroczyły marginesu błędu. W tym samym roku wartość wskaźnika Portugalii przekroczyła wartość dziesięciu państw EŚW. W analizowanym roku identyczną wartość wskaźnika portugalskiego osiągnęła tylko Polska. Natomiast w 2019 r. - podobnie jak w 2017 r. - portugalski wskaźnik przekroczył wartość wszystkich jedenastu państw EŚW. Podobną sytuację zaobserwowano jedynie w Polsce, Estonii oraz Czechach, gdzie omawiany wskaźnik osiągnął wartość około 66\%. We wszystkich przypadkach wartość wskaźników państw Europy Północnej przewyższały wartości zarówno państw EŚW, jak i państw Europy Południowej.

Tabela 4

Zadowolenie obywateli ze sposobu funkcjonowania demokracji w ich państwie w państwach Europy Północnej, Południowej i Środkowo-Wschodniej na podstawie Eurobarometr

\begin{tabular}{|c|c|c|c|c|}
\hline \multirow[b]{2}{*}{ Państwo } & \multicolumn{4}{|c|}{$\begin{array}{l}\text { Wskazania wg terminów badań \% odpowiedzi „bardzo } \\
\text { zadowolony(a)” i „raczej zadowolony(a)”. }\end{array}$} \\
\hline & 2016 & 2017 & 2018 & 2019 \\
\hline 1 & 2 & 3 & 4 & 5 \\
\hline \multicolumn{5}{|l|}{ Europa Pólnocna } \\
\hline Dania & 88 & 92 & 91 & 95 \\
\hline Finlandia & 77 & 81 & 81 & 84 \\
\hline Szwecja & 80 & 85 & 81 & 80 \\
\hline \multicolumn{5}{|l|}{ Europa Południowa } \\
\hline Grecja & 17 & 23 & 26 & 35 \\
\hline Hiszpania & 32 & 43 & 40 & 50 \\
\hline Portugalia & 45 & 72 & 64 & 68 \\
\hline
\end{tabular}

${ }^{6}$ Eurobarometr jest międzynarodowym projektem systematycznej analizy opinii publicznej realizowany na zlecenie Komisji Europejskiej. Jego metodologia opiera się na bezpośrednich wywiadach kwestionariuszu przeprowadzonych przez instytucje zrzeszone w ESOMAR. Specyfika badania składa się z około tysiąca bezpośrednich wywiadów z każdego państwa. Analiza ta nie tylko wskazuje, w których państwach członkowskich UE obywatele wykazują największe zadowolenie z ustroju, ale także kładzie akcent na kontekst, w jakim ustroju funkcjonują. 


\begin{tabular}{|l|c|c|c|c||}
\hline \multicolumn{1}{|c|}{1} & 2 & 3 & 4 & 5 \\
\hline Europa Środkowo-Wschodnia & 50 & 61 & 64 & 66 \\
\hline Polska & 30 & 32 & 35 & 51 \\
\hline Litwa & 53 & 52 & 59 & 56 \\
\hline Łotwa & 51 & 57 & 61 & 66 \\
\hline Estonia & 58 & 63 & 60 & 65 \\
\hline Czechy & 38 & 41 & 45 & 54 \\
\hline Słowacja & 30 & 42 & 41 & 51 \\
\hline Słowenia & 31 & 33 & 34 & 40 \\
\hline Rumunia & 32 & 27 & 35 & 33 \\
\hline Chorwacja & 31 & 39 & 35 & 40 \\
\hline Bułgaria & 34 & 50 & 53 & 58 \\
\hline Węgry & 81,7 & 86 & 84,3 & 86,3 \\
\hline Średnia & 31,3 & 46 & 43,3 & 51 \\
\hline Państwa Europy Północnej & 39,8 & 45,1 & 47,4 & 52,7 \\
\hline Państwa Europy Południowej
\end{tabular}

Nie uwzględniono danych za 2020 r. Eurobarometr nie opublikował jeszcze tych danych.

Źródło: Opracowanie własne na podstawie: Public opinion.., 2019, s. 125.

\section{Prawa polityczne i swobody obywatelskie}

Freedom House sporządza coroczny globalny raport Freedom in the World ${ }^{7}$ o stanie demokracji i wolności we wszystkich państwach świata. Raport jest narzędziem monitorującym zmiany w obszarze przestrzegania i ochrony przez władze państwowe praw politycznych i wolności obywatelskich. W tabeli 5 zaprezentowano wskaźniki dla grupy państw Europy Północnej, Południowej i Środkowo-Wschodniej opracowane przez Freedom House w latach 2017-2020.

Indeksy wolności politycznej wszystkich Państw Europy Północnej w latach 20172020 były wyższe od wskaźników dla państw Europy Południowej, a zatem ogólna ocena państw Europy Północnej jest wyższa. Wszystkie trzy państwa skandynawskie osiągnęły wysoki stopień wolności politycznej tj. 100 pkt Szwecja i Finlandia, a Dania 97 pkt. We wspomnianych latach Portugalia jako jedyne państwo Europy Południowej osiągnęła wysoki indeks wolności politycznej (96,5 pkt). Reasumując, państwa Europy

${ }^{7}$ Metodologia sporządzonego corocznego raportu przez Freedom House wywodzi się w głównej mierze z Powszechnej Deklaracji Praw Człowieka. Podczas analizy bada się demokrację w dwóch kluczowych obszarach, a mianowicie w obszarze prawa politycznego oraz obszarze swobód obywatelskich. Zespół ekspertów odpowiada na pytania przypisane do poszczególnych obszarów demokracji (w obszarze swobód obywatelskich opracowano piętnaście pytań, natomiast w obszarze praw politycznych występuje dziesięć pytań ogólnych, z czego dwa pytania mają charakter anonimowy, dotyczące niektórych państw. Odpowiedzi oceniono w skali od 0 do 4 pkt i oparto o bardziej dokładne wskaźniki przypisane do każdego pytania. Większa ilość uzyskanych punktów świadczy o wyższym poziomie wolności w danym obszarze. Analiza zawiera następujące opisy systemów politycznych: 1) obszar praw politycznych, 2) obszar swobód obywatelskich. W całości indeks składa się z 17 pytań oraz 146 przypisanych im wskaźników. Suma punktów uzyskanych w każdym z ocenianych dwóch obszarach zostaje proporcjonalnie przeliczona na ocenę poziomu wolności w danej kategorii. Końcowym wskaźnikiem stanu demokracji i wolności jest średnia ocena z obu kategorii (Szewczyk, 2010, s. 123-124). 


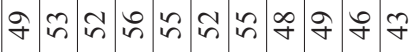

ริ)

莡

ฮิ สิ

$\pi \stackrel{5}{*}$

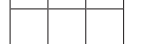

(

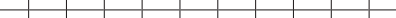

ब.

ค

아아 क

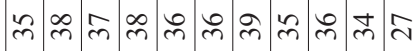

ลूล

ขึ

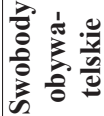

in 8 B $\bar{n} \operatorname{nin}$

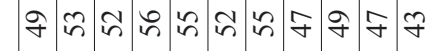

을

约

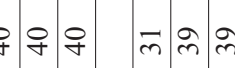

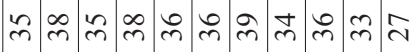

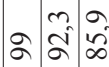

बי

胥

a

宅 를

2. 8 t t

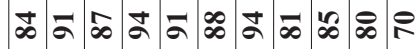

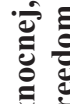

它

资

in 88 은

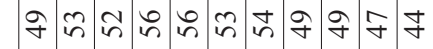

늘

客.

$\stackrel{\infty}{2}$

胥

$\stackrel{乛}{\sharp}$

앙ㅇㅇㅇㅛ

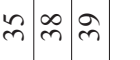

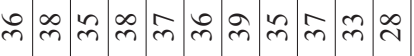

ลสล

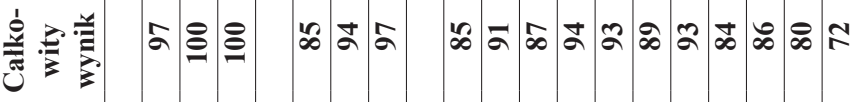

突

in 80

gิ $\infty$

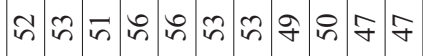

b

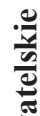

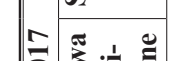

id o

m $\infty \underset{m}{\infty}$ mे

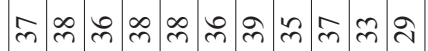

ละิล

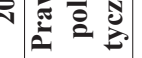

ลูย ๘

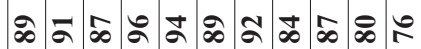

$\frac{2}{0}$

 吾产

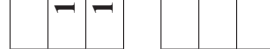

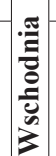

竞

(1)

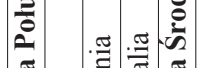

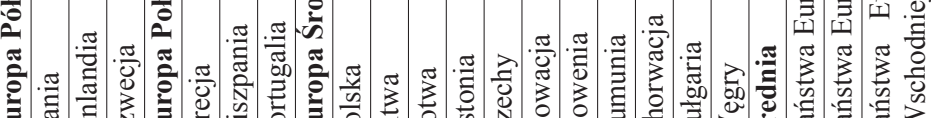


Południowej osiągnęły w tym czasie wyższe wartości indeksów w porównaniu z państwami EŚW.

Niemniej jednak ocena poszczególnych wskaźników państw Europy Południowej z 2020 r. na podstawie dwóch obszarów, tj. praw politycznych i swobód obywatelskich, nie jest lepsza od poszczególnych państw EŚW. Odnotować można w tym kontekście, że wartość wskaźnika dla Grecji przekroczyła wartość sześciu państw EŚW w analizowanym roku. Natomiast wartość wskaźnika dla Hiszpanii przekroczyła wartość wskaźnika Estonii i Słowenii.

Porównując zarówno wskaźniki praw politycznych i swobód obywatelskich oraz ogólny indeks wolności politycznej - obserwuje się wyraźne różnice między poszczególnymi państwami Europy Południowej i Środkowo-Wschodniej. Jedynie nieznaczna różnica występuje między Grecją a pozostałymi państwami Europy Południowej. W przypadku EŚW zwiększa się różnica wolności demokracji między Węgrami a pozostałymi państwami regionu.

Istotny jest również fakt, iż rok 2020 jest 15. rokiem z rzędu, w którym odnotowano spadek poziomu wolności politycznej w grupie państw EŚW. W 2017 r. różnica między dwiema grupami państw Europy Południowej a Środkowo-Wschodniej wyniosła 4 pkt (Freedom in...2017), w 2018 r. 5,6 pkt, w 2019 r. 6,4 pkt, a w 2020 r. aż 8,4 pkt. Największą dynamikę spadku poziomu praw i wolności politycznej odnotowują Węgry (spadek z 76 pkt do 70 pkt) oraz Polska (spadek z 89 pkt do 84 pkt), co oznacza, że oba państwa w większym tempie odchodzą od standardów wielu wysoko rozwiniętych państw UE, do których dążono w okresie transformacji ustrojowej i akcesji tych państw do UE. Ponadto, na przestrzeni ostatnich czterech lat, zaobserwowano wzrost poziomu powyższych praw i wolności wyłącznie na Łotwie i Słowenii. Oznacza to, że spadek wskaźników wolności jest problemem nie tylko regionu EŚW, ale również całej Unii Europejskiej.

\section{Wolność prasy}

Porównując średnie wartości indeksów wolności prasy z państw Europy Południowej i Środkowo-Wschodniej (tabela 6), zauważyć można, że średnie z państw EŚW były niższe od średnich z państw Europy Południowej we wszystkich trzech analizowanych latach za wyjątkiem roku 2016. Oznacza to, że sytuacja mediów w państwach Europy Południowej jest lepsza w porównaniu z państwami EŚW. W ocenie Freedom House średnia wartości wskaźników dla państw Europy Południowej wskazuje na lepszą pozycję mediów, niemniej jednak różnica ta jest stosunkowo niewielka. Zgodnie z rankingiem Reporters Without Borders w obu grupach państw sytuacja w tym obszarze pogorszyła się dynamicznie w latach 2016-2020 w odniesieniu do lat 2005-2010 (World Press..., 2010) ${ }^{8}$. Analiza danych pokazuje, że w latach 2016-2020 nie ma wyraźnych różnic między tymi dwiema grupami.

8 Średnia dla grupy państw Europy Południowej w 2005 r. wyniosła 5,72, w 2010 r. - 14,54. Średnia dla grupy państw Europy Środkowo-Wschodniej w 2005 r. wyniosła 3,03, natomiast w 2010 r. 7,3. Por. World Press Freedom Index 2005 i 2010, https://rsf.org/en/world-press-freedom-index-2010. 
Ocena Freedom House ${ }^{9}$ wskazuje na występowanie wyraźnych różnic w indeksach wolności mediów pomiędzy państwami nordyckimi a pozostałymi grupami państw tj. państwami południowymi oraz państwami należącymi do Europy Środkowej i Wschodniej. Przykładowo w 2016 r. średnia wartość dla indeksu państw nordyckich wyniosła 9,93 pkt, a dla państw Europy Południowej 22,51 pkt, zatem różnica między dwiema grupami państw była znacząco duża i wyniosła 12,58 pkt. Natomiast średnia wartość dla indeksu grupy państw nordyckich w 2020 r. wyniosła 8,44 pkt, a dla państw EŚW 24,56 pkt, czyli różnica między wspomnianymi grupami państw wyniosła aż 16,12 pkt. Tabela 6 wskazuje również na wyraźne różnice w ocenie dla pozostałych trzech indeksów z lat 2017, 2018 i 2019.

Tabela 6

Indeks wolności prasy w grupach państw Europy Północnej, Południowej i Środkowo-Wschodniej na podstawie Press Freedom Index w latach 2016-2020

\begin{tabular}{|c|c|c|c|c|c|}
\hline Państwo & 2016 & 2017 & 2018 & 2019 & 2020 \\
\hline 1 & 2 & 3 & 4 & 5 & 6 \\
\hline \multicolumn{6}{|l|}{ Europa Pólnocna } \\
\hline Dania & 8,89 & 10,36 & 13,99 & 9,87 & 8,13 \\
\hline Finlandia & 8,59 & 8,92 & 10,26 & 7,90 & 7,93 \\
\hline Szwecja & 12,33 & 8,27 & 8,31 & 8,31 & 9,25 \\
\hline \multicolumn{6}{|l|}{ Europa Południowa } \\
\hline Grecja & 30,35 & 30,89 & 29,19 & 29,08 & 28,80 \\
\hline Hiszpania & 19,92 & 18,69 & 20,51 & 21,99 & 22,16 \\
\hline Portugalia & 17,27 & 15,77 & 14,17 & 12,63 & 11,83 \\
\hline \multicolumn{6}{|c|}{ Europa Środkowo-Wschodnia } \\
\hline Polska & 23,89 & 26,47 & 26,59 & 28,89 & 28,65 \\
\hline Litwa & 19,95 & 21,37 & 22,20 & 22,06 & 21,19 \\
\hline Łotwa & 17,38 & 18,62 & 19,63 & 19,53 & 18,56 \\
\hline Estonia & 14,31 & 13,55 & 14,08 & 12,27 & 12,61 \\
\hline Czechy & 16,66 & 16,91 & 21,89 & 24,89 & 23,57 \\
\hline Słowacja & 13,26 & 15,51 & 20,26 & 23,58 & 22,67 \\
\hline Rumunia & 24,29 & 24,46 & 23,65 & 25,67 & 25,91 \\
\hline Chorwacja & 27,91 & 29,59 & 28,94 & 29,03 & 28,51 \\
\hline Bułgaria & 34,46 & 35,01 & 35,22 & 35,11 & 35,06 \\
\hline Słowenia & 22,26 & 21,57 & 21,69 & 22,31 & 22,64 \\
\hline Węgry & 28,17 & 29,01 & 29,11 & 30,44 & 30,84 \\
\hline
\end{tabular}

${ }^{9}$ Indeks wolności prasy opracowano na podstawie internetowego kwestionariusza stworzonego przez międzynarodową organizację pozarządową Reporterzy bez Granic, badającą wolność prasy na całym świecie. Do udziału w badaniu zaproszono dziennikarzy, socjologów, prawników oraz innych specjalistów w sferze mediów z wytypowanych państw. Zebrane informacje odzwierciedlają stopień wolności dziennikarzy, społeczności internetowej oraz mediów informacyjnych. Listę 87. pytań utworzono na podstawie ankiet wysyłanych do organizacji partnerskich oraz dziennikarzy, pracowników naukowych, sędziów, a także działaczy praw człowieka. Do najważniejszych elementów oceny, które decydują o wolności mediów w danym państwie, należy zaliczyć pluralizm mediów, ich niezależność, środowisko i autocenzura, aktualne prawo państwa, transparentność instytucji i procedur, infrastrukturę, a także obecność prześladowań. Ranking opiera się na punktacji według skali od 0 do 100 pkt, z czego najniższy wynik jest najlepszym, tzn. 0-15 pkt - dobra sytuacja; $15,01-25$ pkt - sytuacja satysfakcjonująca; 25,01-35 pkt - zauważalne problemy; 35,01-55 pkt trudna sytuacja; 55,01-100 pkt - bardzo poważna sytuacja (How the...,2020). 


\begin{tabular}{|c|c|c|c|c|c|}
\hline 1 & 2 & 3 & 4 & 5 & 6 \\
\hline \multicolumn{6}{|l|}{ Średnia } \\
\hline Państwa Europy Północnej & 9,93 & 9,18 & 10,80 & 8,69 & 8,44 \\
\hline Państwa Europy Południowej & 22,51 & 21,78 & 21,30 & 21,23 & 20,93 \\
\hline Państwa Europy Środkowo-Wschodniej & 22,05 & 22,91 & 23,93 & 24,89 & 24,56 \\
\hline
\end{tabular}

Źródło: Opracowanie własne na podstawie: Press Freedom..., 2020.

W latach 2016-2020 indeksy dla państw Europy Północnej nieznacznie się wahały. W przypadku państw Europy Południowej wspomniane wskaźniki polepszyły się, co uwidaczniało pozytywnie zmieniającą się sytuację w zakresie wolności mediów. W dalszym ciągu, we wspomnianym przedziale czasowym, uległy obniżeniu indeksy wolności prasy w państwach EŚW.

Według rankingu Freedom House media wszystkich analizowanych państw zostały ocenione jako „wolne”. W latach 2019 i 2020, z uwagi na upolitycznione regulacje medialne i narastającą dominację mediów zależnych od rządu, najbardziej niekomfortową sytuację w tym obszarze zaobserwowano na Węgrzech. W Polsce, Rumunii, Chorwacji oraz na Węgrzech odnotowano wyniki w przedziale 25-35 pkt, co sugeruje ,zauważalne problemy" w omawianym temacie. Ponadto w Bułgarii indeks wyniósł 35 pkt, co dało podstawę stwierdzenia „trudnej sytuacji” medialnej w tym państwie.

Od 2015 r. największe tempo pogarszającej się sytuacji w zakresie wolności mediów odnotowuje Polska (z 12,71 pkt w 2015 r. do 28,65 pkt w 2020 r.), Czechy (z 11,62 pkt w 2015 r. do 23,57 pkt w 2020 r.) oraz Słowacja (z 11,66 pkt w 2015 r. do 22,67 pkt w 2020 r.). Oznacza to, że powyższe państwa zaczynają w większym tempie odbiegać od wielu wysoko rozwiniętych państw UE, do których dążono od momentu akcesji do Unii (Dzień wolności..., 2015). Ponadto na przestrzeni ostatnich pięciu lat wzrost poziomu wolności mediów zaobserwowano jedynie tylko w Estonii. Zatem obniżenie wskaźników indeksu wolności prasy, a co za tym idzie ograniczenie wolności mediów, jest problemem regionu EŚW, jak i całej UE.

\section{Wnioski}

Analiza danych w niniejszym tekście polegała w głównej mierze na przeglądzie i porównaniu wskaźników stosowanych do oceny jakości demokracji w trzech grupach państw tj. Europy Północnej, Południowej i Środkowo-Wschodniej. Porównując grupy państw południowoeuropejskich z państwami EŚW można stwierdzić, że wyższą jakość kryterium demokracji spełniają państwa pierwszej grupy. Państwa Europy Południowej, w odniesieniu do Europy Północnej, cechowały się wyższymi średnimi w każdej z omawianych kategorii, co świadczy o wyższej jakości demokracji w tym regionie. Warto jednak podkreślić, że sumaryczne dane liczbowe wskaźników użytych podczas prowadzonej analizy są jedynie orientacyjne, gdyż mają one inny charakter, znaczenie oraz metodologię wyznaczania.

Analiza rozpatrywanych wskaźników - podobnie jak analizy zaprezentowane przez Spurgisa w latach 2006-2010 - ujawniła kilka trendów. Po pierwsze, podczas analizy wskaźników dla poszczególnych państw wykazano, że we wszystkich przypadkach 
nie ma ścisłych różnic pomiędzy państwami Europy Południowej i EŚW. Wartości poszczególnych indeksów państw Europy Południowej i EŚW często były identyczne, przy czym wartości wskaźników państw EŚW, częściowo spełniających kryteria wysokiej jakości demokracji, przewyższały najniższe wskaźniki z poszczególnych państw Europy Południowej. Indeksy grup państw Europy Północnej i Południowej, spełniających kryteria wysokiej jakości demokracji, znacząco od siebie odbiegają, co sugeruje wyższą jakość demokracji w państwach nordyckich. Tym samym różnice w jakości demokracji, podobnie jak w latach 2006-2010, w ramach grupy starych demokracji (członków UE) są większe niż różnice między państwami EŚW a państwami Europy Południowej.

Po drugie, obserwuje się, że wartości wskaźników jakości demokracji w państwach EŚW z biegiem lat spadają, podczas gdy w państwach Europy Południowej i Północnej wskaźniki są stabilne lub stopniowo polepszają się.

Po trzecie, najbardziej wyróżniającym się z badanych elementów było zadowolenie obywateli ze sposobu funkcjonowania demokracji w ich państwie. Według tego kryterium państwa EŚW bardziej odpowiadają cechom demokracji wysokiej jakości niż państwa Europy Południowej.

Po czwarte, różnice pomiędzy średnimi wskaźnikami państw Europy Północnej i Południowej, które odpowiadają cechom demokracji wyższej jakości, były w wielu przypadkach znacznie większe niż różnice pomiędzy państwami Europy Południowej i EŚW.

Niepokojący jest fakt, iż w ostatnich wyborach krajowych i europarlamentarnych odnotowano wzrost poparcia dla skrajnie prawicowych partii politycznych, traktujących nacjonalizm jako element kultury politycznej dla europejskiego krajobrazu politycznego (Nacjonalizm w..., 2019; Śliwiński, 2005, s. 127) ${ }^{10}$. Niemniej jednak przedwczesne byłoby stwierdzenie, iż mamy do czynienia z odwrotem od demokracji w grupie państw EŚW. Natomiast faktem jest, iż postkomunistyczne państwa przestają już spełniać kryteria skonsolidowanej demokracji zgodnie z teorią Juana J. Linza lub Alfreda Stepana, gdzie o demokracji skonsolidowanej w państwie mówi się wtedy, gdy reguły demokratyczne stają się ,jednymi możliwymi regułami gry w mieście” (Linz, Stepan, 1996, s. 5-6). Jest jednak oczywiste, że system demokratyczny w państwach Europy Południowej i EŚW nie jest tak stabilny, jak np. w państwach Europy Północnej. Próbując znaleźć odpowiedź na pytanie, dlaczego system demokratyczny w państwach Europy Południowej nie jest dostatecznie stabilny i napotyka pewne problemy, nasuwa się odpowiedź, iż znaczący w tym przypadku jest wpływ historycznych doświadczeń tych państw, które doświadczyły przewrotów wojskowych i rozpoczęły swoją drogę demokratyczną stosunkowo późno, bo w latach 80 . XX wieku. Istotne znaczenie ma w tym kontekście zapewne także poziom rozwoju gospodarczego w analizowanych grupach państw. Powyższe stanowi potwierdzenie tego, że podążanie drogą demokracji jest złożonym, niejednoznacznym i długim procesem.

Oceniając wyniki przeprowadzonej analizy można stwierdzić, że sytuacja demokracji państw EŚW i starych państw członkowskich UE jest porównywalna. Nie ma w tym przypadku powodu, aby mówić o odmienności cywilizacyjno-kulturowej tych dwóch grup państw.

10 Należy zauważyć, iż z elementem nacjonalizmu i populizmu mieliśmy do czynienia w okresie międzywojennym, gdzie były przedsionkiem dyktatury i autorytaryzmu. 


\section{Bibliografia}

Dahl R. (2012), Demokracja i jej krytycy, tłum. S. Amsterdamski, Warszawa.

Diamond L., Morlino L. (2004), The Quality of Democracy. an Overview, "Journal of Democracy", $\mathrm{nr} 4$.

Dzień wolności prasy: Gdzie na świecie jest najgorsza cenzura, Raport (2015), https://www.polityka. pl/tygodnikpolityka/swiat/1617931,1,dzien-wolnosci-prasy-gdzie-na-swiecie-jest-najgorszacenzura.read, 15.02.2021.

Economist Intelligence Unit, Report (2013), https://pl.wikipedia.org/wiki/Wska\%C5\%BAnik_demokracji.

Economist Intelligence Unit, Report (2019), https:/www.in.gr/wp-content/uploads/2020/01/Democracy-Index-2019.pdfhttps://www.in.gr/wp-content/uploads/2020/01/Democracy-Index-2019. pdf, 15.02.2021.

Freedom in the World 2017. Report (2017) Populists and Autocrats: The Dual Threat to Global Democracy, https://freedomhouse.org/report/freedom-world/freedom-world-2017, 15.02.2021.

Freedom House. Report (2020), https://freedomhouse.org/countries/freedom-world/scores, 15.02.2021.

Gastil R. D. (1990), The Comparative Survey of Freedom: Experiences and Suggestions, „Studies in Comparative International Development", vol. 25, $\mathrm{nr} 1$.

How the Index is Compiled (2020), https://rsf.org/en/detailed-methodology, 15.02.2021.

Nacjonalizm w Europie. BBC prezentuje ranking (2019), https://www.dw.com/pl/nacjonalizm-w-europie-bbc-prezentuje-ranking/a-51271134, 15.02.2021.

Press Freedom Index 2020. Report (2020), https://rsf.org/en/ranking/2020.

Public opinion in the European Union 2019, Report (2019), https://ec.europa.eu/commfrontoffice/ publicopinion/index.cfm/general/doChangeLocale/locale/EN/curEvent/WhatsNew.index/ WhatsNew/index//, 15.02.2021.

Linz J. J., Stepan A. (1996), Problems of Democratic Transition and Consolidation - Southern europe, South america, and Post-Communist europe, The Johns Hopkins University Press, BaltimoreLondon.

Kapsa I., Musiał-Karg M. (2020), Alternatywne metody głosowania w opiniach Polaków. Postawy i poglady względem wybranych form partycypacji w wyborach, UAM WNPiD, Poznań.

Schopfin G. (1994), Postcommunism: The Problems of Democratic Construction, Deda-lus $123 \mathrm{Nr} 3$.

Schumpeter J. A. (2009), Kapitalizm, socjalizm, demokracja, thum. M. Rusiński, Warszawa 2009.

Spurga S. (2011), Pokomunizmas po dvidešimt metų: Siaurès Europos valstybiu, Pietu Europos valstybiu ir Vidurio ir Rytu Europos valstybiu demokratijos rodikliu palyginimas, „Politologija” nr 4.

Śliwiński M. (2005), Analiza porównawcza systemów politycznych. Drogi do wspótczesności, vol. 1, Drogi do wspótczesności, Wydawnictwo Uniwersytetu Warszawskiego, Warszawa.

Szewczyk W. (2010), Jak zmierzyć demokrację? Teoretyczne i metodologiczne podstawy budowy skal demokracji politycznej w politologii porównawczej, „Przegląd Politologiczny” nr 4.

World Press Freedom Index 2005 i 2010. Report (2010), https://rsf.org/en/world-press-freedom-index-2010, 15.02.2021.

Wyniki wyborów europejskich w 2019 r. Report (2019), https://www.europarl.europa.eu/election-results-2019/pl/frekwencja/, 15.02.2021. 


\title{
Democracy quality indicators in European regions in 2016-2020. Towards the erosion of democracy in the countries of Central and Eastern Europe?
}

\begin{abstract}
Summary
A common feature in the countries of Central and Eastern Europe (CEE) seems to be a fairly similar level of quality of democracy. The aim of the article is to analyze whether the CEE countries are in the proces of retreat from democracy and whether there are clear differences in the level of development of democracy between the old EU countries and other EU countries. The indicators of the quality of democracy in the groups of CEE, North, South and West countries were assessed. The analysis revealed, similarly to the previous research by Lithuanian political scientist Saulius Spurga, that there is no clear difference between the indicators of the CEE group and the group of Southern European countries (including Spain, Portugal, Greece). On the other hand, in the case of Scandinavian and Southern European countries, there are significant differences in the level of democracy indicators. The data clearly show a higher level of quality of democracy in the Nordic countries. This is confirmed by the results of democracy quality reports from 2006, 2008 and 2010. Based on the analysis performed, it can be concluded that the differences in the quality of democracy in the group of old EU Member States are greater than the differences between the CEE countries and the countries of Southern Europe.
\end{abstract}

Key words: Northern Europe, Southern Europe, CEE, democracy, indexes, indicators, quality of democracy 
